\title{
PENDIDIKAN KARAKTER MELALUI PEMBELAJARAN BERNYANYI PADA MATA KULIAH KONSEP PENDIDIKAN SENI 1 SD DI STKIP NASIONAL PADANG PARIAMAN
}

\author{
WINDA FEBRIANTI SARI
}

winda_febrianti_sari@yahoo.com

\begin{abstract}
Implementation of character education through learning to sing in the concept of art education 1 SD at STKIP Nasional Padang Pariaman in music, there are 3 meetings for singing material, 1 meeting for material and singing theory and the next meeting is continued with singing practice accompanied by a lecturer, then at the last meeting will be assessed with a practice exam singing with the concept of a choir. Determining the types of songs to be performed is also a way for prospective elementary school (SD) teachers to enrich their compulsory, national and regional songs in Indonesia. By implementing this method, students are familiar with national compulsory songs and regional songs. When the meeting on singing material begins, students will be provided with knowledge about what is vocal, what is singing, how to breathe, articulation in singing, choir and so on. In the next meeting, students will practice in the classroom accompanied by a lecturer. It was only at the next meeting that the practical test of singing was carried out, and the results were very satisfying. The character values shown by students in learning singing in the art education concept course 1 SD At STKIP Nasional Padang Pariaman, there are a lot of them, namely, religious, honest, tolerance, discipline, hard work, creative, independent, democratic, curiosity, enthusiasm. nationality, love the homeland and love the archipelago, responsibility and many more.
\end{abstract}

Keywords: Character Education, Singing, Art Education Concept.

Abstrak: Implementasi pendidikan karakter melalui pembelajaran bernyanyi pada mata kuliah konsep pendidikan seni 1 SD di STKIP Nasional Padang Pariaman pada seni musik ada 3 kali pertemuan untuk materi bernyanyi, 1 kali pertemuan untuk materi dan teori bernyanyi dan pertemuan selanjutnya dilanjutkan dengan latihan bernyanyi didampingi dosen, kemudian pada pertemuan terakhir akan dinilai dengan ujian praktek bernyanyi dengan konsep paduan suara. Penentuan jenis lagu yang akan ditampilkan juga suatu cara agar para calon guru Sekolah Dasar (SD) ini bisa memperkaya kasanah lagu-lagu wajib, nasional dan lagu daerah yang ada di Indonesia. Dengan mengimplementasikan cara tersebut, maka mahasiswa terbiasa dengan lagulagu wajib nasional dan lagu daerah. saat pertemuan tentang materi bernyanyi dimulai, mahasiswa akan dibekali ilmu seputar apa itu vokal, apa itu bernyanyi, bagaimana pernafasan, artikulasi dalam bernyanyi, paduan suara dan lain sebagainya. pertemuan selanjutnya, mahasiswa akan berlatih di dalam kelas dengan didampingi oleh dosen. Pada pertemuan selanjutnya barulah ujian praktek dari bernyanyi dilakukan, dan hasilnya pun sangat memuaskan. Nilai-nilai karakter yang ditunjukan mahasiswa dalam pembelajaran bernyanyi pada mata kuliah konsep pendidikan seni 1 SD Di STKIP Nasional Padang Pariaman ada banyak sekali yaitu, religius, jujur, toleransi, disiplin, kerja keras, kreatif, mandiri, demokratis, rasa ingin tahu, semangat kebangsaan, Cinta tanah air dan cinta Nusantara, tanggung jawab dan masih banyak lagi.

Kata Kunci: Pendidikan Karakter, Bernyanyi, Konsep Pendidikan Seni. 


\section{A. Pendahuluan}

Salah satu perguruan tinggi yang akan mencetak calon guru adalah Sekolah Tinggi Keguruan dan Ilmu Pendidikan (STKIP) Nasional, salah satunya adalah calon guru Sekolah Dasar (SD) melalui prodi Pendidikan Guru Sekolah Dasar (PGSD), yang mana mahasiswa di sini akan menjadi seorang guru yang akan mendidik siswa/siswinya menjadi siswa yang berkarakter, maka dari itu mahasiswa dan mahasiswi di sini harus berkarakter pula.

Pada zaman sekarang generasi muda sudah banyak terpapar dengan pengaruh budaya luar yang negatif. Krisis moralitas, etika dan budi pekerti yang makin hari makin terkikis oleh perkembangan zaman dan teknologi, membuat banyak generasi muda lupa pada kebudayaan dan karakter sebagai warga negara Indonesia. Untuk itu, agar mahasiswa dan mahasiswi menjadi seseorang yang berkarakter maka perlu dibimbing agar karakter mereka sebagai calon seorang guru harus dipupuk dari awal, melalui perkuliahan. Berangkat dari hal tersebut peneliti tertarik untuk meneliti "Pendidikan Karakter melalui Pembelajaran Bernyanyi Pada Mata Kuliah Konsep Pendidikan Seni 1 SD di STKIP Nasional Padang Pariaman".

\section{B. Metodologi Penelitian}

Metodologi penelitian yang dipakai disesuiakan dengan kebutuhan dari penelitian ini, yang akan menghasilkan dan membahas pendidikan karakter melalui pembelajaran bernyanyi pada mata kuliah konsep pendidikan seni 1 SD di STKIP Nasional Padang Pariaman.

\section{Hasil dan Pembahasan}

\section{Implementasi Pendidikan Karakter Melalui Pembelajaran Bernyanyi pada Mata} Kuliah Konsep Pendidikan Seni 1 SD di STKIP Nasional Padang Pariaman

Pada awal perkuliahan diberikan kontrak perkuliahan, serta pembagian kelompok diskusi dan kelompok untuk ujian praktek paduan suara, serta jenis lagu dan jumlah lagu yang harus dipilih untuk ujian praktek. Jenis lagunya adalah pilih 1 buah lagu wajib atau lagu nasional dan pilih 1 buah lagu daerah. Jadi total lagu yang akan diujikan adalah 2 buah lagu untuk masing-masing kelompok, dengan catatan judul lagu antara satu kelompok dengan kelompok yang lain tidak boleh sama. Untuk pemilihan jenis lagu, memang dosen yang menentukan, hal ini dilakukan sebagai salah satu implementasi penddidikan karakter pada mahasiswa Sekolah Tinggi Keguruan dan Ilmu Pendidikan (STKIP) Nasional Padang Pariaman, Prodi Pedidikan Guru Sekolah Dasar (PGSD). Penentuan jenis lagu ini juga suatu cara agar para calon guru Sekolah Dasar (SD) ini bisa memperkaya kasanah lagu-lagu wajib, nasional dan lagu daerah yang ada di Indonesia. Mengingat guru Sekolah Dasar (SD) harus menguasai banyak lagu untuk diajarkannya pada peserta didiknya kelak.

Dengan mengimplementasikan cara tersebut, maka mahasiswa terbiasa dengan lagu-lagu wajib nasional dan lagu daerah, karena bagaimanapun pendidikan adalah agen pertumbuhan pribadi manusia (education as growth), yakni mengoptimalkan "kapasitas" (capacity) atau "kemampuan" (ability) mereka, agar di dalam diri mereka terbentuk kebiasaan-kebiasaan yang secara terus menerus disesuaikan dengan kondisikondisi baru. Kebiasaan-kebiasaan yang dosen inginkan adalah kebiasaan dari mahasiswa menyanyikan lagu wajib, lagu nasional serta lagu daerah, sebab semua itu adalah asset negara Indonesia. Sebagai generasi muda diera globalisasi yang arusnya tak terbendung lagi ini, pemuda-pemuda atau mahasiswa dan mahasiswi hanya tahu 
dengan lagu dari negara-negara asing, sementara dengan lagu kebangsaan, lagu wajib, lagu nasional serta lagu daerah juga tidak dipedulikan, maka lama-lama semua jenis lagu tersebut akan hilang dan musnah karena tergeser perkembangaan zaman dan teknnologi.

Tahapan selanjutnya ialah selama jadwal materi bernyanyi belum dimulai, namun dosen sudah menginformasikan bahwa seluruh kelompok harus memilih judul lagu yang akan dilatih dan ditampilkan, dan tidak boleh sama dengan kelompok lain. Setelah mereka berdiskusi untuk memilih lagu, dosen meminta seluruh mahasiswa untuk berlatih dengan kelompok masing-masing di luar jam perkuliahan. Pada kondisi ini jelas dosen ingin mahasiswa mencari tahu dahulu bagaimana bernyanyi yang baik dan berlatih paduan suara dengan teman-teman mereka. Durasi mereka sangat panjang dalam berlatih bersama kelompok, saat pertemuan tentang materi bernyanyi dimulai, mahasiswa akan dibekali ilmu seputar apa itu vokal, apa itu bernyanyi, bagaimana pernafasan, artikulasi dalam bernyanyi, paduan suara dan lain sebagainya. Kemudian pada pertemuan selanjutnya, mahasiswa akan berlatih di dalam kelas dengan didampingi oleh dosen. Dosen akan mendengarkan serta mengkoreksi dari keseluruhn lagu dan penampilan masing-masing kelompok serta menjelaskan bagaimana yang seharusnya, dengan mencontohkan dan melatih hingga kelompok benar-benar paham dan benar-benar bisa.

Pada pertemuan selanjutnya barulah ujian praktek dari bernyanyi dilakukan, dan hasilnya pun sangat memuaskan. Walaupun diawal kontrak perkuliahan mereka banyak yang mengatakan tidak bisa atau tidak berbakat, bahkan mengaku kalau vokal mereka tidak bagus, namun hasilnya berbeda, mereka mampu dan bisa menampilkan yang terbaik. Semua itu tidak terlepas dari latihan yang rutin dan bersungguh-sungguh secara mandiri, serta pengetahuan secara teori dan praktek serta bimbingan, pengajaran, arahan dan latihan dari dosen pula.

\section{Nilai-Nilai Karakter yang Ditunjukan Mahasiswa dalam Pembelajaran Bernyanyi pada Mata Kuliah Konsep Pendidikan Seni 1 SD Di STKIP Nasional Padang Pariaman}

Ada banyak sekali nilai-nilai karakter yaitu, religius, jujur, toleransi, disiplin, kerja keras, kreatif, mandiri, demokratis, rasa ingin tahu, semangat kebangsaan, Cinta tanah air dan cinta Nusantara, tanggung jawab dan masih banyak lagi.

Religius, sebagaimana yang diketahui, bahwa banyak lagu wajib/nasional dan lagu daerah yang menggambarkan kebesaran Tuhan YME. Dengan menghafal, dan berlatih lagu-lagu tersebut, cinta mereka kepada Tuhan YME serta rasa syukur yang mendalam lama-kelamaan akan terpupuk, karna sering dinyanyikan.

Jujur, mahasiswa jujur ketika ditanya apakah sudah berlatih mandiri dengan kelompok, mereka akan menjawab dengan jujur. Mereka sudah tahu bahwa usaha yang sedikit akan menghasilkan hasil latihan yang kurang baik. Jadi mereka sudah paham, berdusta pun tiada berguna, karena nanti saat dosen melihat penampilan mereka dosen akan tahu bahwa mereka kurang dalam berlatih.

Toleransi, dengan berkelompok mahasiswa belajar untuk bertoleransi dengan temannya, mulai dari lokasi latihan yang disepakati bersama titik lokasi mana yang terdekat untuk semua anggota kelompok. Serta jika ada teman yaang memang suaranya fales, mereka tidak serta merta membiarkan begitu saja, namun akan dibantu untuk lebih baik lagi. 
Disiplinm dengan latihan terus menerus melatih mahasiswa untuk disiplin. Bernyanyi dengan aturan atau teknik yang sudah diajarkan dosen akan mendisiplinkan mahasiswa bahwa bernyanyi itu tidak boleh assal-asalan.

Kerja keras, dikarenakan ingin hasil yang maksimal saat ujian praktek bernyanyi, maka mereka semua bekerja keras dalam latihan dan berusaha dengan giat memperbaiki setiap kesalahan secara berkelompok.

Kreatif, belajar seni tentu dituntut dengan kreatifitas yang tinggi pula, sebab dosen tidak pernah membatasi mahasiswa dalam mengeksplorasi kemampuan mereka, sehinga mahasiswa pun belomba-lomba dalam mengkreasikan lagu yang mereka pilih.

Mandiri, tugas berkelompok yang diberikan dosen menjadi tugas mandiri, yang melatih mahasiswa untuk bisa saling bertanggung jawab atas kelompok mereka dan mereka harus bisa meng-handle teman-teman yang mungkin tidak se ide atau tidak sejalan dengan mereka, agar kelompok mereka bisa menjadi yang terbaik.

Demokratis, tentulah mahasiswa boleh berpendpat atau mempunyai ide, karena kelompok yang meng-handle mereka sendiri, jadi semua kreatifitas, kebebasan dalam berpendapat, komentar yang membangun demi keberhasilan kelompok sangat diperlukan

Rasa ingin tahu, rasa ingin tahu tenu haaus dimiliki oleh mahasswa, dalam hal ini mahassswa selalu ingin tau dalam ilmu teori dan praktek bernyaanyi yang benaar agar keloompook mereka dapat berlatih dengan beenar dan enampilkan hasil yaang maksimaal.

Semangat kebangsaan, Cinta tanah air dan cinta Nusantara, tujuan dosen membatasi jenis lagu kepada mahasiswa adalah salah satunya agar mahasiswa tumbuh semangat kebangsaan, cinta tanah air dan cinta Nusantara, karena lagu kebangsaan, lagu wajib ataupun lagu naasional, serta lagu daerah yang dilatih terus menerus serta dinyanyikan dengan benar akan menumbuhkan rasa semangat kebangsaan, cinta tanah air dan cinta Nusantara.

Tanggung jawab, mahasiswa sangat bertanggung jawab dengan tugas-tugas yang diberikan dosen. Mereka melakukan latihan dengan ikhlas dan penuh tanggung jawab, sebab bernyanyi itu menyenangkan.

\section{Daftar Pustaka}

Emzir, (2010). Metodologi Penelitian Kualitatif Analisis Data. Jakarta: Raja Grafindo Persada

Lestari, Yuni Sri. (2016), Implementasi Pendidikan Karakter Melalui Kegiatan Ekstrakurikuler Seni Tari di Sekolah Dasar Negeri 1 Trirenggo Tahun Pelajaran 2015/2016, Jurnal Program Studi Pendidikan Guru Sekolah Dasar, Universitas Sarjanawiyata Tamansiswa

Satya, Bayu DS. (2013). Teknik Dasar Bernyanyi untuk Seolah Dasar \& Menengah. Yogyakarta: ANDI Yogyakarta

Susanto, Ahmad, (2013). Teori Belajar \& Pembelajaran di Sekolah Dasar. Jakarta: Kencana 